\title{
THE AUTONOMIC INNERVATION OF THE RAT TESTICULAR CAPSULE
}

\author{
G. BELL AND J. R. MaLEAN \\ Department of Zoology, University of Melbourne, \\ Parkville 3052, Victoria, Australia
}

(Received 3rd January 1972)

\begin{abstract}
Summary. The autonomic innervation of the rat testicular capsule has been investigated pharmacologically and histochemically. Electrical field stimulation of isolated capsules produced contractile responses which were abolished, or largely depressed, in the presence of bretylium ( 2 to $4 \times 10^{-6} \mathrm{~g} / \mathrm{ml}$ ). Any residual response was abolished in the presence of hyoscine $\left(5 \times 10^{-7} \mathrm{~g} / \mathrm{ml}\right)$. No evidence for the presence of a relaxatory innervation was obtained. Fluorescence histochemistry demonstrated the existence of a dense plexus of fine varicose fibres exhibiting catecholamine fluorescence in the mediastinal region, and of more scattered fluorescent fibres in other areas. The blood vessels in the region of the rete testis also received a dense innervation by fluorescent fibres. Fibres which stained heavily for acetylcholinesterase were sparsely distributed in the mediastinal and non-mediastinal regions of the capsule, but were absent from the blood vessels. It is concluded that the capsule receives both adrenergic and cholinergic motor nerves, the adrenergic supply predominating, and that acetylcholinesterase positivity can be used as a criterion of cholinergic autonomic nerves in the rat, at least with the preparative conditions employed by us.
\end{abstract}

\section{INTRODUCTION}

The testicular capsules of various mammals, including man, have been shown to contain smooth muscle cells which are concentrated along the mediastinal axis (Shioda \& Nishida, 1966; Holstein \& Weiss, 1967; Holstein, 1967; Davis, Langford \& Kirby, 1970).

It has been reported recently that isolated capsular preparations from rat and rabbit contract in response to exogenous noradrenaline, adrenaline and acetylcholine, and on the basis of this evidence it has been proposed that the testicular capsule is autonomically innervated and that it may be physiologically important in movement of spermatozoa from the testis (Davis \& Langford, 1969; Davis et al., 1970). However, although apparent efferent nerve fibres have been reported to be present in the testicular capsules of bull (Shioda \& Nishida, 1966), monkey and man (Baumgarten, 1968), there is no precise evidence regarding the innervation of the capsular smooth muscle. The present investigation was concerned with clarification of this situation in the rat. 


\section{MATERIALS AND METHODS}

Male Sprague-Dawley and Hooded rats, weighing $250 \mathrm{~g}$ or more, were stunned and exsanguinated. The testes were exposed and removed from their tissue attachments.

Testicular capsules for pharmacological investigation were removed from the underlying testicular tissue as described by Davis et al. (1970) and suspended in an organ bath of modified Krebs' solution (Huković, 1961) maintained at $36.5^{\circ} \mathrm{C}$. The caudal pole of the capsule, i.e. that opposite to the point of exit of the rete, was attached by a thread to a Grass FTO3 isometric transducer, with a resting tension on the tissue of about $200 \mathrm{mg}$. Field stimulation of the capsule was elicited with platinum ring electrodes placed around the rostral pole of the tissue. These electrodes were $10 \mathrm{~mm}$ in diameter, $6 \mathrm{~mm}$ apart and were used to deliver 0.1 to $0.4 \mathrm{msec}$ square wave pulses from a Grass S4 stimulator at rates of 10 to 60 pulses/sec. The applied voltage was $60 \mathrm{~V}$ and $10-\mathrm{sec}$ trains of pulses were delivered at 3- to 4-min intervals. The drugs used were atropine sulphate (BDH), bretylium tosylate (Burroughs-Wellcome), dexamphetamine sulphate $(\mathrm{BDH})$, hyoscine hydrobromide (David Bull) and noradrenaline bitartrate (Winthrop).

For histochemical investigation, the testicular capsules were cut open along their longitudinal axis, cleaned of adhering seminiferous tubules and pinned out on paraffin wax. Tissue for fluorescent examination was freeze-dried and exposed to formaldehyde vapour for visualization of catecholamines, as described by Falck \& Owman (1965), using the whole-mount preparation procedure described by McLean \& Burnstock (1966). Tissue for cholinesterase staining was fixed overnight in $10 \%$ formalin containing $0.44 \mathrm{M}$-sucrose (Pearson, 1963) and buffered to $\mathrm{pH} \mathrm{7.3}$ with ammonia. The fixative was washed out in distilled water and the capsules stained by the method of Karnovsky \& Roots (1964), using acetylthiocholine substrate at $\mathrm{pH} 5 \cdot 8$ for a period necessary to produce staining of the cholinergic elements in similarly prepared slices of ileum. Preincubation in $8 \times 10^{-6} \mathrm{M}$-iso-OMPA (tetramono-isopropyl pyrophosphortetramide) for 40 to $60 \mathrm{~min}$ was used to inhibit pseudocholinesterase activity (Aldridge, 1953; Austin \& Berry, 1953). In some experiments, 1:5-bis (4-allyldimethyl ammoniumphenyl) pentane-3-diiodide (BW284C51), in a concentration of $5 \times 10^{-6} \mathrm{M}$, was present in both preincubation and incubation media to inhibit acetylcholinesterase (Holmstedt, 1957). The tissues were cleared and examined as whole mounts under ultraviolet light, direct light and phase contrast conditions.

\section{RESULTS}

\section{Pharmacology}

Capsular preparations from eight white Sprague-Dawley and two Hooded rats were examined.

Transmural stimulation evoked contraction of the capsules, maximum responses being obtained at about 40 pulses/sec. These responses were approximately equal in size to contractions elicited by noradrenaline in a concentration 
of $1 \times 10^{-7} \mathrm{~g} / \mathrm{ml}$. Reproducible responses to stimulation were obtained using a 10 -sec stimulation period and an interval between stimulation periods of 3.5 to $4 \mathrm{~min}$. Addition of bretylium tosylate $\left(2\right.$ to $\left.4 \times 10^{-6} \mathrm{~g} / \mathrm{ml}\right)$ to the bath caused reduction and abolition of the response to stimulation within three to five periods of stimulation in eight of twelve experiments, abolition being more rapid with higher stimulation frequencies. In the remaining experiments, bretylium caused only a 50 to $90 \%$ reduction of responses. The response to noradrenaline $\left(1 \times 10^{-7} \mathrm{~g} / \mathrm{ml}\right)$ was not appreciably affected by the presence of bretylium. Following abolition of the response to stimulation, addition to the bath of dexamphetamine sulphate $\left(5\right.$ to $\left.10 \times 10^{-6} \mathrm{~g} / \mathrm{ml}\right)$ produced partial or total restoration of the response within two stimulation periods, even in the continued presence of bretylium (Text-fig. 1a).
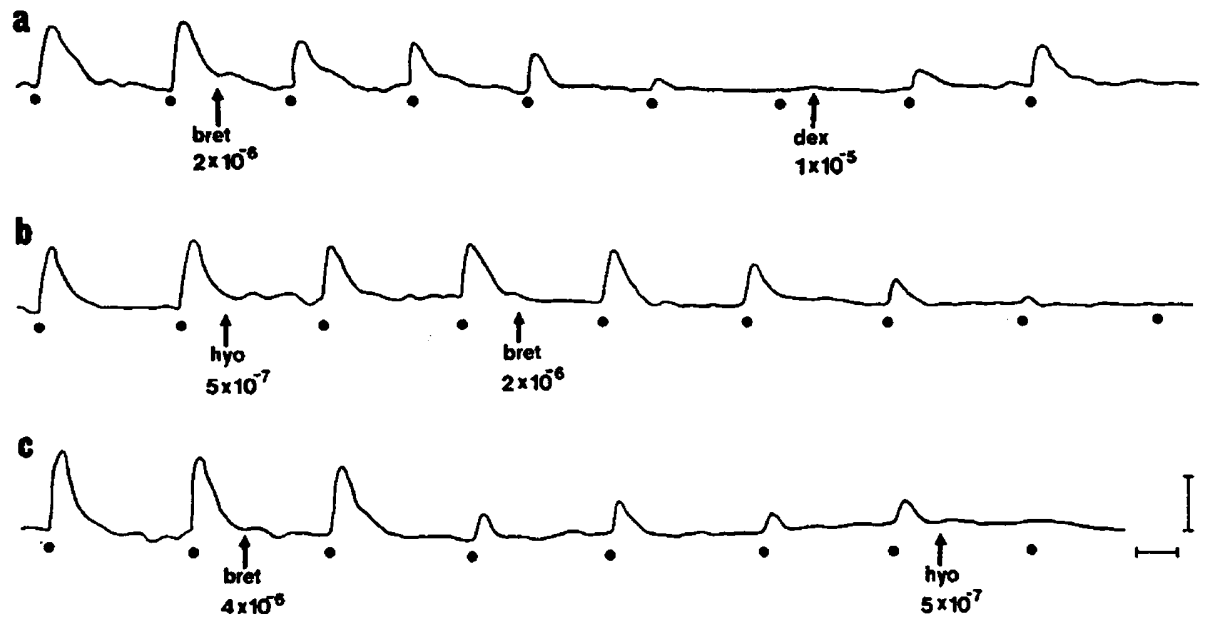

Text-Fig. 1. Contractile responses of isolated preparations of rat testicular capsules to electrical field stimulation at 20 pulses/sec (black dots). Calibrations: $20 \mathrm{mg}$ and $1 \mathrm{~min}$. (a) Abolition of responses in the presence of bretylium $\left(2 \times 10^{-6} \mathrm{~g} / \mathrm{ml}\right)$, and subsequent restoration by addition of dexamphetamine $\left(1 \times 10^{-5} \mathrm{~g} / \mathrm{ml}\right)$. (b) Reduction of responses in the presence of hyoscine $\left(5 \times 10^{-7} \mathrm{~g} / \mathrm{ml}\right)$, and abolition of the remaining response in the presence of bretylium $\left(2 \times 10^{-6} \mathrm{~g} / \mathrm{ml}\right)$. (c) Abolition of the residual response in the presence of hyoscine $\left(1 \times 10^{-7} \mathrm{~g} / \mathrm{ml}\right)$ in a preparation where bretylium $\left(4 \times 10^{-6} \mathrm{~g}\right)$ $\mathrm{ml}$ ) produced only partial blockade.

Atropine $\left(10^{-6} \mathrm{~g} / \mathrm{ml}\right)$ caused a $20 \%$ reduction in responses to stimulation in two preparations, and hyoscine $\left(5 \times 10^{-7} \mathrm{~g} / \mathrm{ml}\right)$ caused $20 \%$ reduction in response in one preparation (Text-fig. 1b) and had no effect in a further two preparations. In three of the four preparations in which bretylium caused only incomplete abolition of responses, the remaining response was abolished by application of hyoscine $\left(5 \times 10^{-7} \mathrm{~g} / \mathrm{ml}\right)$ (Text-fig. 1c). Following abolition of the contractile response to stimulation with bretylium, no relaxatory response to stimulation was observed.

\section{Histochemistry}

Although some variation was seen in the density and distribution of fluorescent nerves in individual testicular capsules the following general statements can be made. 
The blood vessels entering the capsule at the rete testis received a relatively dense adrenergic innervation (Pl. 1, Fig. 3). This extended for only a short distance, and was totally absent from vessels more than a few millimetres away from the rete. In the mediastinal region, particularly in that area surrounding the rete, there were also large numbers of fine, ramifying adrenergic fibres having the varicose appearance of terminal effector plexuses as seen in other tissues (Hillarp, 1959; Norberg \& Hamberger, 1964; Malmfors, 1965). Although these fibres appeared sometimes to arise from the same population of nerves that supplied the capsular blood vessels, they could clearly be seen to lie in areas remote from vessels (Pl. 1, Figs 1 and 2). Larger non-terminal fluorescent nerves, which also entered the capsule at the rete, could be traced into the non-mediastinal areas of the capsule, where they gave rise to scattered, varicose terminal fibres which branched and terminated (Pl. 2, Fig. 4). In some instances, these varicose fibres formed plexuses of bizarre geometrical regularity over small areas of the capsular tissue (Pl. 2, Fig. 5).

Nerves exhibiting an acetylcholinesterase (AChE) reaction similar in intensity to that seen in intestinal cholinergic elements from the same animal were sparsely distributed through the non-mediastinal areas of the capsule (Pl. 2, Figs 6 and 7). These nerves gave rise to extremely fine branches, some of which appeared to be varicose. In some preparations, AChE-positive fibres were also seen as a sparse plexus along the mediastinum. By contrast with the distribution of adrenergic fibres, no fibres exhibiting a strong AChEreaction were associated with the capsular blood vessels. If, however, the staining was prolonged for at least four times the period necessary to reveal the initial pattern of AChE distribution, then plexuses of weakly AChE-positive fibres became visible around the blood vessels in the region of the rete testis. These fibres presumably represented the adrenergic population.

Unlike the adrenergic nerves, the nerves which exhibited a strong AChEreaction appeared to enter the capsule at points some distance from the rete testis.

\section{DISCUSSION}

Isolated preparations of the rat testicular capsule contracted in response to transmural electrical stimulation. This contraction was mimicked by exogenous noradrenaline, was abolished in most experiments by the adrenergic neuroneblocking agent, bretylium, without abolition of the response to noradrenaline itself and was restored by amphetamine. These results strongly suggest the

\section{EXPLANATION OF PLATE 1}

Catecholamine fluorescence in whole-mount preparations of the testicular capsule of the rat following freeze-drying and hot formaldehyde gas treatment for $1 \mathrm{hr}$. Calibrations $100 \mu \mathrm{m}$.

FIG. 1. Fine fluorescent varicose nerves ramify extensively over the mediastinum. Occasionally these nerves accompany fine blood vessels (bv).

FIG. 2. Numerous fluorescent varicose fibres branching and running parallel to each other along the mediastinum.

FIG. 3. Dense innervation of the larger blood vessels entering the capsule at the rete. 

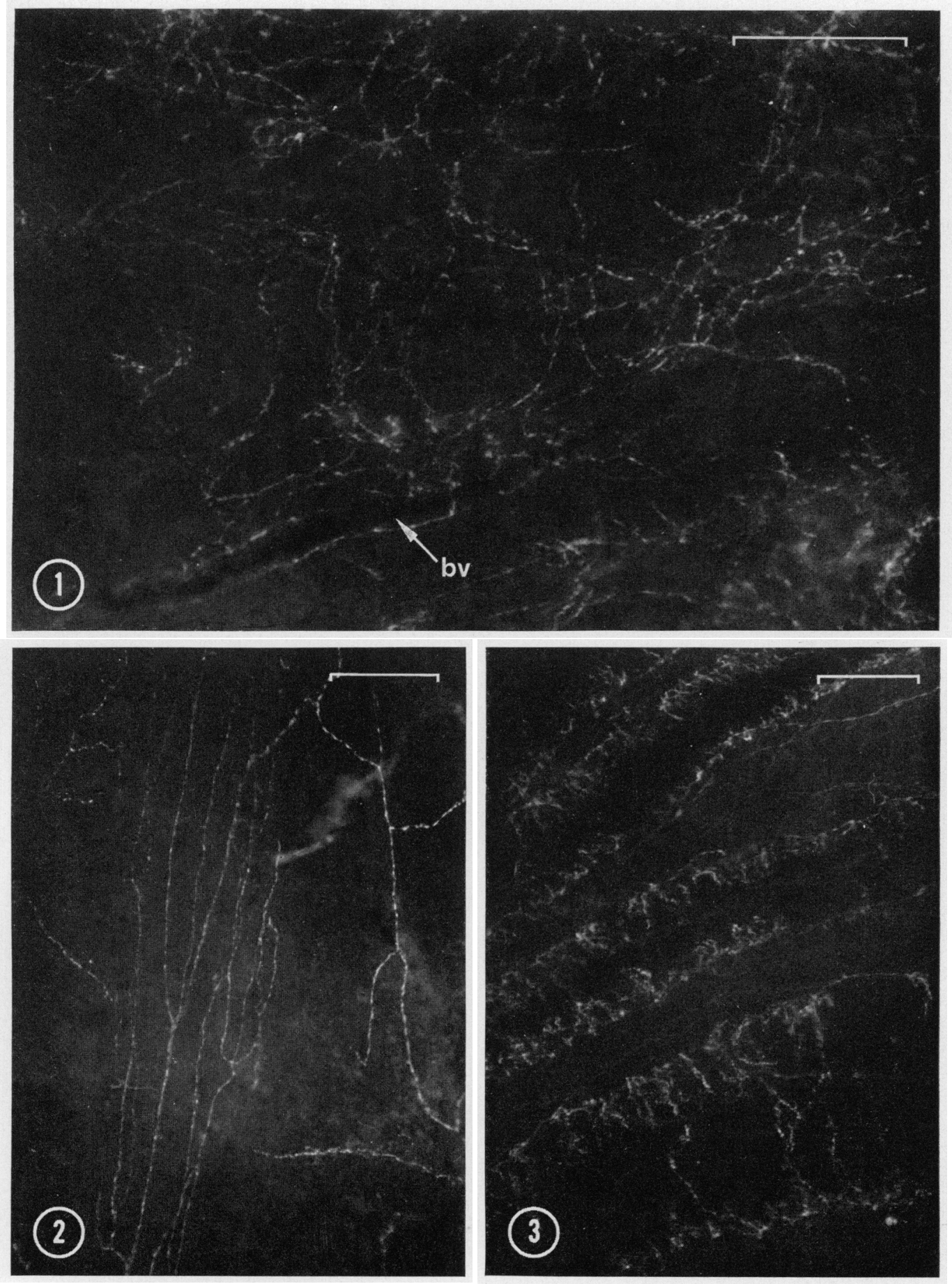
PLA'l'i ?
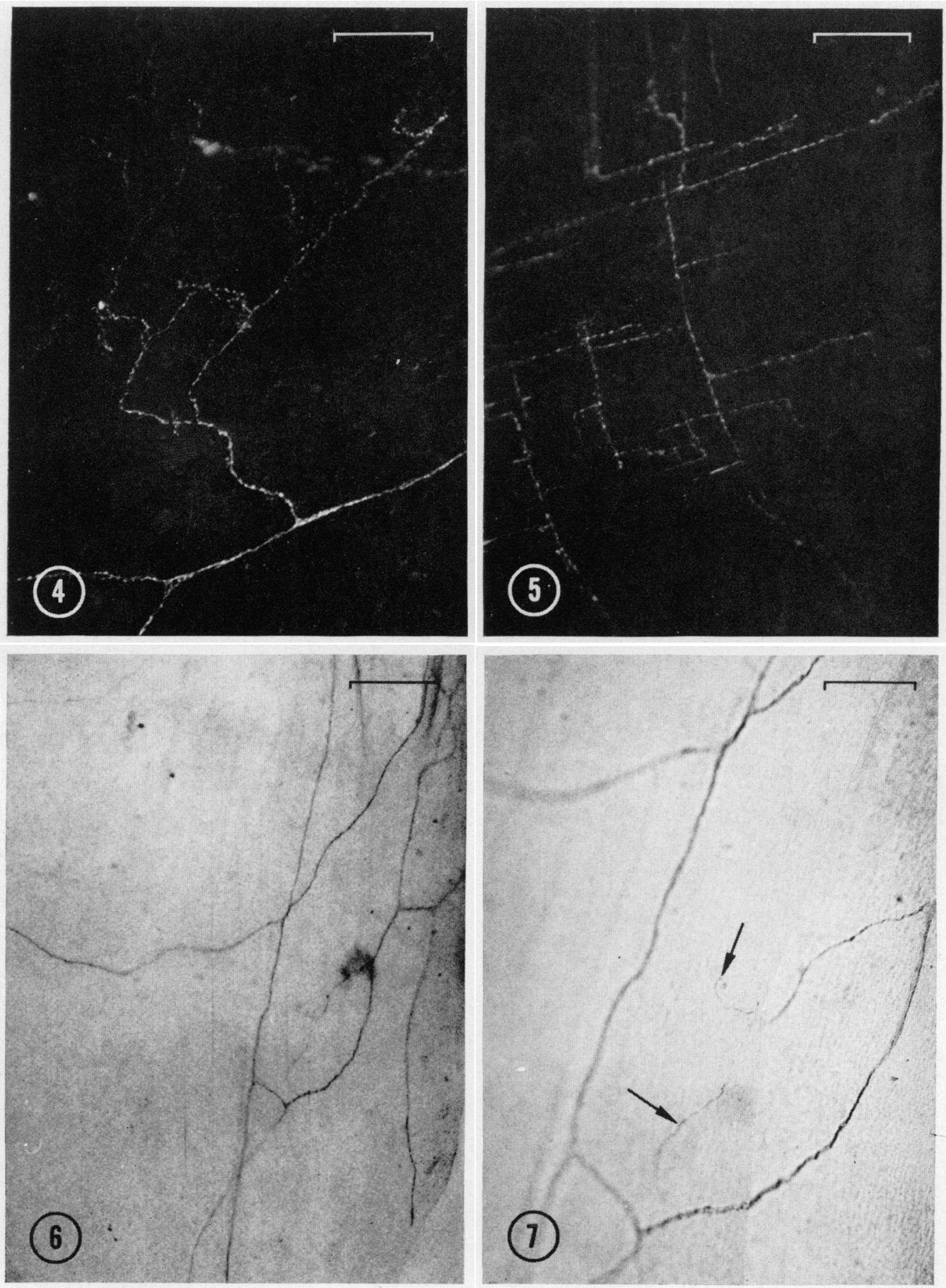

(Facing p. 257) 
presence of adrenergic motor nerves in the capsular muscle. Such a proposition was confirmed by the histochemical localization of noradrenaline in numbers of fine nerve fibres which resembled the terminal adrenergic plexuses in other tissues and which were not associated with blood vessels.

The demonstration of a population of AChE-positive nerves having a distribution different from that of the fluorescent fibres suggested the presence of an independent cholinergic supply to the capsular muscle. This was confirmed by the facts that atropine and hyoscine caused some reduction of contractile responses to electrical stimulation, and abolished the residual responses in those preparations where bretylium caused only incomplete blockade. Thus, the capsular muscle appears to be supplied by both adrenergic excitatory and cholinergic excitatory fibres. This innervation pattern is similar to that described for other regions of the male genital musculature in rat (Swedin, 1971a) and guinea-pig (Birmingham, 1966; Bell, 1967; Bell \& McLean, 1967).

Although it has been widely accepted that a positive AChE reaction can be used as a criterion of cholinergic nerves, doubt has been cast recently on whether this is valid for the rat (Eränkö, Rechardt, Eränkö \& Cunningham, 1970). Our results indicate that, in this species, cholinergic postganglionic fibres can be differentiated from adrenergic postganglionic fibres on the basis of their AChE-reaction at least at the level of light microscopy, although it seems likely that the validity of this difference is dependent on the preparative procedures employed, in particular the method of fixation.

The presence of an autonomic innervation to the capsular smooth muscle is compatible with the suggestion made by Davis et al. (1970) that the capsule may play an active rôle in extrusion of spermatozoa from the testis, and that the aspermatogenesis consequent upon sympathectomy of the internal genitalia may be related to abolition of this function. The importance of the capsule in testicular function, however, remains doubtful.

Surgical denervation of the internal genitalia of the rat (Swedin, 1971b) and rabbit (Hodson, 1965) produces a massive build-up of spermatozoa in the caput epididymidis, and recently a similar result has been found following pharmacological destruction of the pelvic sympathetic nerve supply in the rat (B. Gannon and B. Evans, personal communication). These data suggest that, at least in the above species, passage of spermatozoa out of the testis is maintained in the absence of a functional capsular innervation, and that the failure of spermatogenesis which results from denervation is more likely to be attributable to back-pressure or to vasomotor disturbances (Hodson, 1965).

\section{EXPLANATION OF PLATE 2}

Whole mount preparations of the rat testis capsule histochemically treated for catecholamine fluorescence (Figs 4 and 5) and for cholinesterase activity (Figs 6 and 7). Calibrations $100 \mu \mathrm{m}$.

Fig. 4. Fluorescent nerve which is remote from the mediastinum and branches into fine varicose terminations.

FIg. 5. Rectangular array of fluorescent varicose fibres forming small plexuses in the non-mediastinum capsular tissue.

Fig. 6. Nerves exhibiting high AChE-reactivity in the non-mediastinal capsular tissue.

Fig. 7. An enlarged view of portion of the field shown in Fig. 6, showing typical fine terminal branches of an AChE-positive nerve (arrowed). 


\section{AGKNOWLEDGMENTS}

This work was assisted by the National Heart Foundation of Australia and by the Australian Research Grants Committee. We should like to thank Professor G. Burnstock for his continued support. We are also grateful to Burroughs Wellcome \& Co. (Australia) Ltd. for generous supplies of BW 284C51 and bretylium tosylate, and to $\mathrm{Dr}$ P. M. Robinson for iso-OMPA.

\section{REFERENCES}

ALDRIDGE, W. N. (1953) The differentiation of true and pseudo cholinesterases by organophosphorus compounds. Biochem. F. 53, 62.

Austin, L. \& Berry, W. K. (1953) Two selective inhibitors of cholinesterase. Biochem. F. 54, 695.

Baumgarten, H. G. (1968) Gited by Hodson, N. (1970) The nerves of the testis, epididymis and scrotum. In: The Testis, Vol. I, p. 47. Eds. A. D. Johnson, W. R. Gomes and N. L. VanDemark. Academic Press, New York.

BeLl, C. (1967) An electrophysiological study of the effects of atropine and physostigmine on transmission to the guinea-pig vas deferens. F. Physiol., Lond. 189, 31.

BeLl, G. \& McLean, J. R. (1967) Localization of norepinephrine and acetylcholinesterase in separate neurons supplying the guinea-pig vas deferens. F. Pharmac. exp. Ther. 157, 69.

Birmingham, A. T. (1966) The potentiation by anticholinesterase drugs on the responses of the guineapig isolated vas deferens to alternate preganglionic and post-ganglionic stimulation. $\mathrm{Br} . \mathcal{J}$. Pharmac. Chemother. 27, 145.

Davis, J. R. \& LANGFoRd, G. A. (1969) Response of the testicular capsule to acetylcholine and noradrenaline. Nature, Lond. 222, 386.

Davis, J. R., Langford, G. A. \& Kirby, P. J. (1970) The testicular capsule. In: The Testis, Vol. I, p. 282. Eds. A. D. Johnson, W. R. Gomes and N. L. VanDemark. Academic Press, New York.

Eränkö, O., Rechardt, L., Eränkö, L. \& Gunningham, A. (1970) Light and electronmicroscopic histochemical observations on cholinesterase-containing sympathetic nerve fibres in the pineal body of the rat. Histochem. F. 2, 479.

FALck, B. \& OWman, C. (1965) A detailed methodological description of the fluorescence method for the cellular demonstration of biogenic monoamines. Acta Univ. lund. Sect. II, No. 7, 1.

HILLARP, N.-A. (1959) The construction and functional organization of the autonomic innervation apparatus. Acta physiol. scand. 46, Suppl. 157.

Hodson, N. (1965) Sympathetic nerves and reproductive organs in the male rabbit. F. Reprod. Fert. 10, 209.

HOLMSTEDT, B. (1957) A modification of the thiocholine method for the determination of cholinesterase. I. Biochemical evaluation of selective inhibitors. Acta physiol. scand. 40, 322.

Holstein, A. F. (1967) Die glatte Muskulatur in der Tunica des Hodens und ihr Einflus auf den Spermatozoentransport in den Nebenhoden. Verh. anat. Ges., Jena, 62, 103.

Holstein, A. F. \& WeIss, C. (1967) U'ber die Wirkung der glatten Muskulatur in der Tunica Albuginea im Hoden der Kaninchens; Messungen des interstitiellen Druckes. Z. ges. exp. Med. 142, 334.

Huković, S. (1961) Responses of the isolated sympathetic nerve-ductus deferens preparation of the guinea-pig. Br. F. Pharmac. Chemother. 16, 188.

Karnovsky, M. J. \& Roors, L. (1964) A 'direct-coloring' thiocholine technique for cholinesterase. 7. Histochem. Cytochem. 12, 219.

McLean, J. R. \& BURNSTOcK, G. (1966) Histochemical localization of catecholamines in the urinary bladder of the toad (Bufo marinus). 7. Histochem. Cytochem. 14, 538.

MAlmFors, T. (1965) Studies on adrenergic nerves. The use of rat and mouse iris for direct observations on their physiology and pharmacology at cellular and subcellular levels. Acta physiol. scand. 64, Suppl. 248.

NorberG, K.-A. \& HAMBERger, B. (1964) The sympathetic adrenergic neuron. Some characteristics revealed by histochemical studies on the intraneuronal distribution of the transmitter. Acta physiol. scand. 63, Suppl. 238.

Pearson, C. K. (1963) A formalin-sucrose ammonia fixative for cholinesterases. F. Histochem. Cytochem. 11,665 .

SHIOdA, T. \& NishidA, S. (1966) Innervation of the bull testis. Fap. F. vet. Sci. $28,251$.

SwEDIN, G. (1971a) Studies on neurotransmission mechanisms in the rat and guinea-pig vas deferens. Acta physiol. scand. 81, Suppl. 369.

Swedrn, G. (1971b) Pre- and postganglionic denervation of the vas deferens and accessory male genital glands: short term effects on fertility in the rat. Andrologie, 3, 1 . 